\title{
PENGARUH KEMAMPUAN KOMUNIKASI DAN DISPOSISI MATEMATIS SISWA SMP
}

\author{
Mega Sugondo Putri ${ }^{1}$, Wahyu Hidayat ${ }^{2}$, Rippi Maya ${ }^{3}$ \\ 1,2,3 IKIP Siliwangi, Jl. Terusan Jend. Sudirman Kb. Rumput Cimahi \\ ${ }^{1}$ megasugondoputri@gmail.com, ${ }^{2}$ wahyu@stkipsiliwangi.ac.id, ${ }^{3}$ maya@stkipsiliwangi.ac.id
}

\begin{abstract}
This study aims to analyze in depth the influence of mathematical disposition on mathematical communication ability of junior high school students. The method in this research using correlational method with quantitative approach. The population of this study is all junior high school students in one of the SMP Negeri in West Bandung amounted to 34 students. Instruments in this study using the test of mathematical communication skills as much as 5 items and the scale of mathematical disposition as much as 23 points of statement scale. The result of this research is student's mathematical disposition influenced by $76,5 \%$ then its rest influenced by other factor outside mathematical disposition equal to $23,5 \%$.
\end{abstract}

Keywords: Mathematical Communication, Disposition Mathematical

\begin{abstract}
Abstrak
Tujuan dalam penelitian ini yaitu untuk menganalisis secara mendalam pengaruh disposisi matematis dan kemampuan komunikasi matematis siswa SMP. Penelitian ini menggunakan metode korelasional dengan pendekatan kuantitatif. Populasi penelitian ini adalah seluruh siswa SMP di salah satu SMP Negeri di Bandung Barat berjumlah 34 siswa. Instrumen yang digunakan dalam tes kemampuan komunikasi matematis sebanyak 5 butir soal dan skala disposisi matematis sebanyak 23 butir skala pernyataan. Hasil penelitian ini yaitu kemampuan komunikasi matematis siswa SMP dipengaruhi disposisi matematis siswa sebesar 76,5\% maka sisa nya dipengaruhi oleh faktor lain diluar disposisi matematis sebesar 23,5\%.
\end{abstract}

Kata Kunci: Kemampuan Komunikasi Matematis, Disposisi Matematis

How to cite: Putri, M. S., Hidayat, W., \& Maya, R. (2018). Pengaruh Kemampuan Komunikasi dan Disposisi Matematis Siswa SMP. JPMI - Jurnal Pembelajaran Matematika Inovatif, 1 (4), 525-530.

\section{PENDAHULUAN}

Kemampuan komunikasi adalah merepresentasikan benda nyata, gambar dan diagram dalam ide matematika, mendeskripsikan ide, relasi dan situasi matematis baik secara tercatat maupun yang diucapkan menggunakan gambar maupun grafik dan menjelaskan maupun membuat soal matematika yang sudah dipelajari berdasarkan situasi yang telah diberikan (Elida, 2012).

Kemampuan komunikasi matematis memiliki peran penting sebagai gambaran kemampuan pemahaman siswa persepsi matematis, masalah kontekstual dan konsep ilmu lain. kemampuan komunikasi membuat siswa berbagi pengetahuan bersama temannya (Hidayat, \& Sumarmo, 2013; Rahmi, Nadia, Hasibah, \& Hidayat, 2017; Zakiah, Saomi, Syara, Hidayat, \& Hendriana, 2018). Proses komunikasi tersebut membantu siswa dalam menemukan konsep 
matematis dan membuat generalisasi, maka untuk mempelajari dan mengasah kemampuan komunikasi siswa hendaknya guru membiasakan siswa untuk memecahkan masalah seharihari atau kontekstual dan menghimbau siswa dalam menyampaikan ide nya masing-masing (Hidayat \& Sumarmo, 2013; Isnaeni, \& Maya, 2014).

Berdasarkan fakta dilapangan bahwa komunikasi matematis siswa masih lemah dan jauh dari harapan, siswa kesulitan dalam mengungkapkan atau menjelaskan gagasan dalam bentuk tulisan maupun gambar, dan siswa kurang berani dalam mengemukakan ide matematis maupun pendapat nya sendiri (Zaini, 2014). Sehingga membuat siswa berfikir bahwa matematika adalah mata pelajaran yang problematis, membosankan, menyeramkan dan menakutkan sehingga siswa cenderung menghindari mata pelajaran matematika. Hal ini menyebabkan perkembangan matematika akan memburuk untuk dimasa selanjutnya (Andiyana, Maya, \& Hidayat, 2018; Nasution, 2016).

Kurangnya rasa keingintahuan siswa dan kepercayaan diri siswa pada pembelajaran matematika sangat mempengaruhi hasil pembelajaran yang cenderung rendah. Maka untuk mengatasi sikap pada permasalahan tersebut diperlukan sikap yang tepat yaitu dengan disposisi matematis (Sumarmo, Hidayat, Zulkarnaen, Hamidah, \& Sariningsih, 2012). Disposisi matematis adalah dorongan, kesadaran atau antusiasme untuk mempelajari matematika dan berperilaku positif untuk menyelesaikan pemasalahan matematis dengan percaya diri, gigih atau tekun, bersifat fleksibel dan mencari solusi penyelesaian dalam memecahkan masalah, menunjukkan minat dan rasa keingintahuan yang tinggi, kecenderungan memonitor pola berpikir dan kemampuan sendiri (Mahmudi, Ali. Saputro, 2016).

Berdasarkan latar belakang, tujuan pada penelitian ini yaitu untuk mengetahui pengaruh disposisi matematis siswa terhadap pencapaian kemampuan komunikasi matematis siswa SMP.

\section{METODE}

Metode dalam penelitian ini menggunakan metode korelasional dengan pendekatan kuantitatif yang bertujuan untuk mengetahui secara mendalam pengaruh disposisi matematis siswa terhadap pencapaian kemampuan komunikasi matematis siswa SMP dengan materi segitiga dan segiempat. Populasi pada penelitian ini yaitu semua siswa SMP di kabupaten Bandung Barat pada kelas VII dengan Subjek penelitian sebanyak 34 orang. Instrumen penelitian ini menggunakan tes kemampuan komunikasi matematis sebanyak 5 butir soal dan skala disposisi matematis sebanyak 23 butir skala pernyataan. Data hasil penelitian diolah dan dianalisis menggunakan uji statistika regresi. namun sebelum melakukan uji statistika regresi, dilakukan uji normalitas dan linieritas terlebih dahulu.

\section{HASIL DAN PEMBAHASAN}

\section{Hasil}

Berdasarkan hasil analisis data, bahwa kemampuan komunikasi dan disposisi matematis bahwa berdistribusi normal. Setelah itu dilakukan uji linieritas kemampuan komunikasi dan disposisi matematis berdasarkan pada tabel berikut 
Tabel 1. Uji linieritas kemampuan komunikasi matematis dan disposisi matematis

\begin{tabular}{|c|c|c|c|c|c|c|c|}
\hline & & & Sum of Squares & $\mathrm{df}$ & Mean Square & $\mathrm{F}$ & Sig. \\
\hline disposisi & Between & (Combined) & 10406,249 & 10 & 1040,625 & 15,205 & ,000 \\
\hline metematis * & Groups & Linearity & 9169,428 & 1 & 9169,428 & 133,976 & ,000 \\
\hline \multirow[t]{3}{*}{ komunikasi } & & $\begin{array}{l}\text { Deviation from } \\
\text { Linearity }\end{array}$ & 1236,821 & 9 & 137,425 & 2,008 & ,086 \\
\hline & \multicolumn{2}{|c|}{ Within Groups } & 1574,133 & 23 & 68,441 & & \\
\hline & \multicolumn{2}{|l|}{ Total } & 11980,382 & 33 & & & \\
\hline
\end{tabular}

Berdasarkan hasil uji linieritas terlihat bahwa terdapat hubungan yang linear pada kemampuan komunikasi matematis dan disposisi matematis siswa. Hal ini memperoleh hasil signifikasi sebesar 0,086 (sign $>\alpha=0,05)$.

Setelah itu dilihat pengaruh hubungan antara disposisi matematis dengan kemampuan komunikasi matematis siswa dengan menggunakan uji statistika regresi dengan hasil pengujian tabel sebagai berikut:

Tabel 2. Uji Regresi antara Kemampuan Komunikasi dan Disposisi Matematis

\begin{tabular}{llrrrrr}
\hline Model & & Sum of Squares & df & Mean Square & F & Sig. \\
\hline 1 & Regression & 9169,428 & 1 & 9169,428 & 104,385 &, $000^{\mathrm{b}}$ \\
& Residual & 2810,954 & 32 & 87,842 & & \\
& Total & 11980,382 & 33 & & & \\
\hline
\end{tabular}

a. Dependent Variable: disposisi metematis

b. Predictors: (Constant), komunikasi

Berdasarkan tabel 2, terdapat signifikan sebesar 0,000 (sign $\alpha<0,05$ ) maka terdapat pengaruh antara disposisi matematis dan kemampuan komunikasi matematis siswa. Selain itu, besarnya koefisien korelasi adalah 0,875 sedangkan nilai koefisien determinan adalah 0,765. Hal ini dapat diartikan bahwa disposisi matematis siswa dipengaruhi sebesar 23,7 \% maka sisa nya dipengaruhi oleh faktor lain diluar disposisi matematis sebesar 76,3\%.

Tabel 3. Uji Regeresi Antara Kemampuan Komunikasi dan Disposisi Matematis

\begin{tabular}{|c|c|c|c|c|}
\hline Model & $\mathrm{R}$ & R Square & Adjusted R Square & $\begin{array}{l}\text { Std. Error of the } \\
\text { Estimate }\end{array}$ \\
\hline 1 &, $875^{a}$ & ,765 & ,758 & 9,372 \\
\hline
\end{tabular}

a. Predictors: (Constant), komunikasi

Maka persamaan regresi berdasarkan hasil pengujian tentang disposisi matematis siswa terhadap kemampuan komunikasi matematis adalah sebagai berikut:

$$
Y=-3,642+5,738 x
$$

Hal ini dapat diinterpretasikan bahwa disposisi matematis siswa bernilai 0 (nol), maka terlihat kemampuan komunikasi matematis siswa sebesar -3,642. Sedangkan koefisien dari disposisi matematis siswa bernilai positif. Maka terdapat pengaruh yang positif antara disposisi 
matematis terhadap kemampuan komunikasi matematis siswa. Berdasarkan penyataan tersebut dapat disimpulkan bahwa semakin tinggi disposisi matematis siswa, maka akan semakin tinggi pula kemampuan komunikasi matematis siswa.

\section{Pembahasan}

Berdasarkan hasil analisis data hasil penelitian, terlihat bahwa terdapat pengaruh positif antara disposisi matematis terhadap kemampuan komunikasi matematis siswa, adapun penyebab terjadinya pengaruh positif diantaranya adalah (1) Siswa yang mempunyai sikap disposisi matematis terlihat lebih percaya diri dan bersungguh-sungguh untuk menghadapi kesulitan dalam menjawab masalah yang diberikan (2) siswa yang kurang dalam sikap disposisi matematis cenderung ragu-ragu atau tidak percaya diri dalam menyelesaikan masalah dan mengerjakan masalah dengan apa adanya karena kurangnya pemahaman dalam memahami masalah dan terdapat pemikiran takut salah dalam menjawab masalah yang diberikan. Sedangkan menurut yuanari (Mandur, Kanisius. Sadra, I Wayan. Suparta, 2013) kurangnya prestasi siswa dalam memecahkan masalah matematika karena malu dalam mengemukakan pendapat, kurang tekad untuk bisa dan kurangnya rasa keingintahuan siswa terhadap matematika.

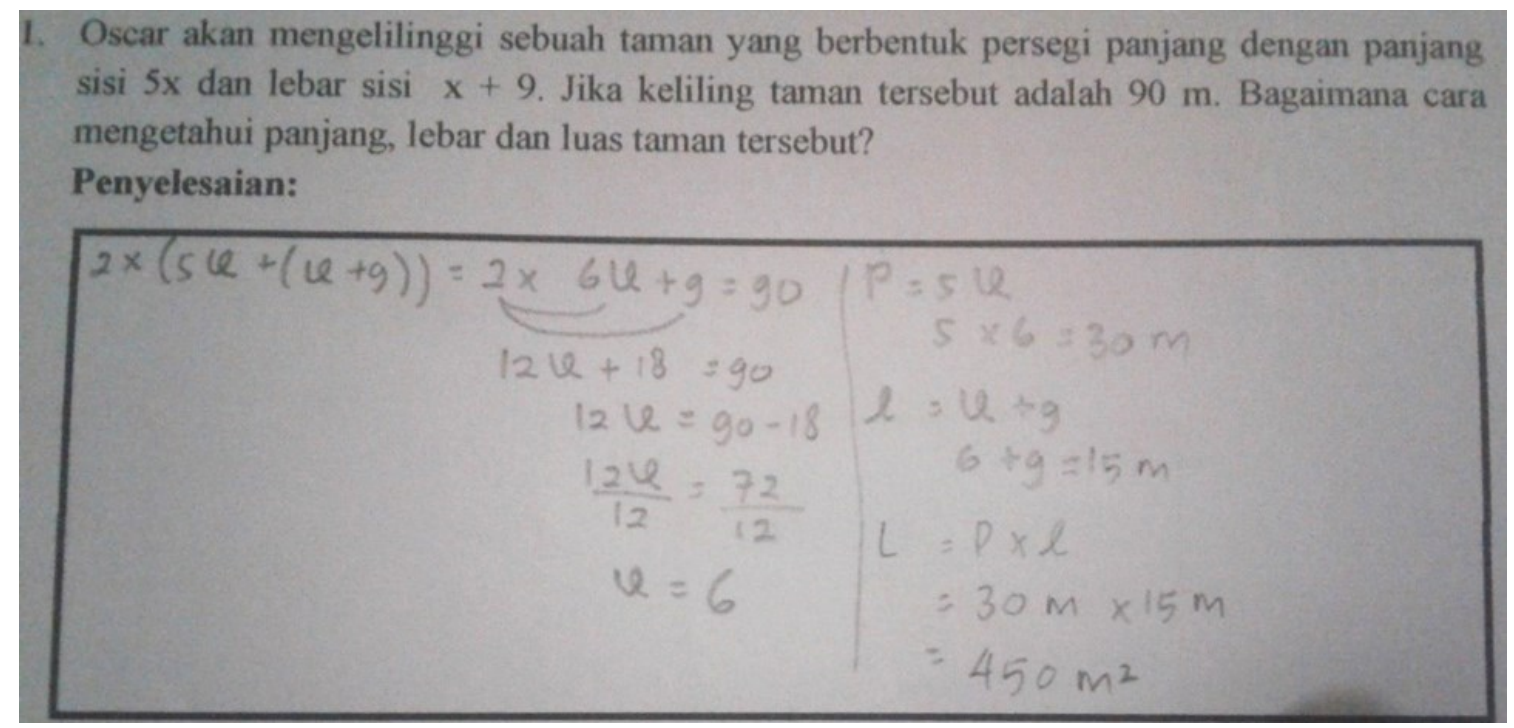

Gambar 1. Hasil jawaban siswa dengan disposisi matematis yang baik

Berdasarkan hasil jawaban siswa pada gambar 1 menunjukkan bahwa siswa yang mempunyai sikap disposisi matematis yang baik dan kemampuan komunikasi yang baik pula. terlihat bahwa siswa sudah mengambil konsep dan strategi yang tepat dalam mengaitkan masalah yang diberikan dengan konsep matematika lain yang sudah dipelajari sebelumnya selain itu siswa juga percaya diri, tekun, pantang menyerah dalam menyelesaikan masalah yang diberikan dan memeriksa kembali jawaban hal ini didukung dengan pendapat NCTM (Mandur, Kanisius. Sadra, I Wayan. Suparta, 2013) bahwa siswa yang mampu mengaitkan ide-ide matematika lainnya pemahaman dan daya ingat yang bagus. sehingga siswa mampu menganalisis keterkaitan antar topik dan pengalaman nya sehari-hari. Siswa yang mempunyai ketekunan yang tinggi dan mampu mengaitkan hubungan antar topik matematika merupakan siswa yang memiliki sikap disposisi matematis yang positif. 


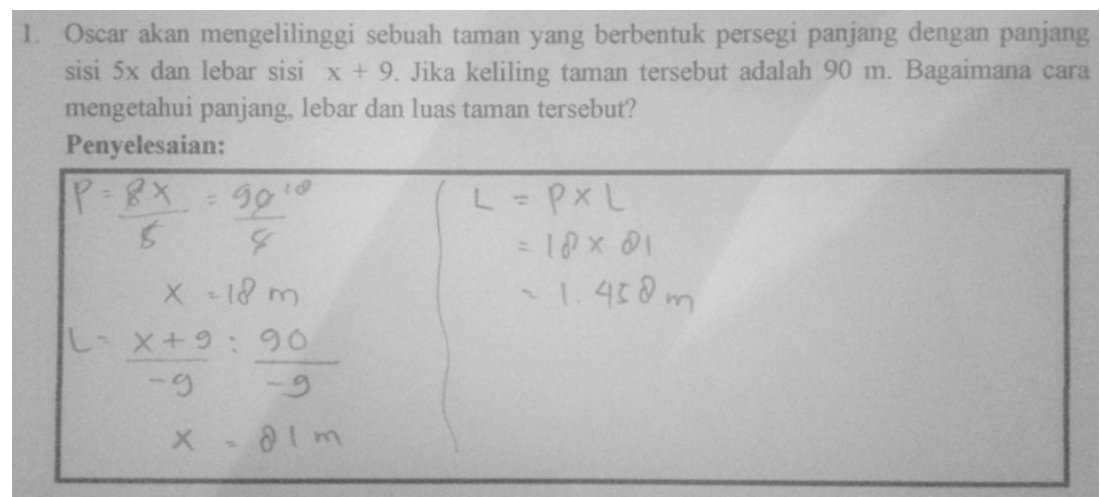

Gambar 2. Hasil Jawaban Siswa dengan Disposisi Matematis Siswa yang Kurang

Berdasarkan hasil jawaban siswa pada gambar 2 menunjukkan bahwa siswa mempunyai kemampuan komunikasi yang kurang dan disposisi matematis yang kurang. Dari hasil jawaban siswa terlihat bahwa siswa sudah paham akan tujuan mencari $\mathrm{x}$ pada masalah yang diberikan akan tetapi tidak menggunakan konsep dan strategi yang tepat sehingga terkesan menebak nebak jawaban. Hal ini disebabkan karena siswa belum dapat memahami permasalahan yang diberikan. selain itu siswa kurang percaya diri, kurangnya ketekunan, kurangnya minat terhadap matematika dan malas untuk mengulang materi yang telah diberikan sebelumnya (Oktaviani, R. Suyitno, 2015).

Berdasarkan hasil penelitian diatas menunjukkan untuk menumbuhkan kemampuan komunikasi dan disposisi matematis siswa diharapkan untuk memahami masalah matematis yang kompleks, memahami konsep-konsep dasar matematis dan sifat pantang menyerah dalam menyelesaikan masalah. Hal tersebut dapat menjadi salah satu penentu keberhasilan seorang siswa dalam pembelajaran matematika (Oktaviani, R. Suyitno, 2015). Hal ini sejalan dengan pendapat NCTM (Choridah, 2013) menyatakan siswa menunjukkan rasa percaya diri, ketertarikan dalam matematika, kegigihan dalam menyelesaikan masalah, memiliki minat yang tinggi, dan senang dalam mempelajari matematika. Jika siswa memiliki sikap dan kebiasaan tersebut maka akan menumbuhkan mathematics disposition (disposisi matematis).

\section{KESIMPULAN}

Berdasarkan hasil penelitian dan pembahasan yang telah disajikan, diperoleh kesimpulan bahwa kemampuan komunikasi matematis siswa SMP dipengaruhi disposisi matematis siswa sebesar 76,5 \% maka sisa nya dipengaruhi oleh faktor lain diluar disposisi matematis sebesar $23,5 \%$.

\section{DAFTAR PUSTAKA}

Andiyana, M. A., Maya, R., \& Hidayat, W. (2018). ANALISIS KEMAMPUAN BERPIKIR KREATIF MATEMATIS SISWA SMP PADA MATERI BANGUN RUANG. JPMI (Jurnal Pembelajaran Matematika Inovatif), 1(3), 239-248.

Choridah, D. T. (2013). Peran pembelajaran berbasis masalah untuk meningkatkan kemampuan komunikasi dan berpikir kreatif serta disposisi matematis siswa sma. Infinity, 2(2), 194-202.

Elida, N. (2012). Meningkatkan kemampuan komunikasi matematik siswa sekolah menengah 
pertama melalui pembelajaran think-talk-write (ttw). Infinity, 1(2), 179. Retrieved from http://www.e-

journal.stkipsiliwangi.ac.id/index.php/infinity/article/view/17/16\%0Ac:\%5CUsers\%5CA CER\%5CDownloads\%5CDocuments\%5C209-278.pdf

Hidayat, W., \& Sumarmo, U. (2013). Kemampuan Komunikasi dan Berpikir Logis Matematik serta Kemandirian Belajar: Eksperimen terhadap Siswa SMA Menggunakan Pembelajaran Berbasis dan Strategi Think-Talk-Write. Delta-Pi: Jurnal Matematika Dan Pendidikan Matematika, 2(1), 1-14.

Isnaeni, I., \& Maya, R. (2014). MENINGKATKAN KEMAMPUAN KOMUNIKASI DAN DISPOSISI MATEMATIK SISWA SEKOLAH MENENGAH ATAS MELALUI PEMBELAJARAN GENERATIF. Jurnal Pengajaran MIPA, 19(2), 159-165.

Mahmudi, Ali. Saputro, B. A. (2016). Analisis Pengaruh Disposisi Matematis, Kemampuan Berpikir Kreatif, dan Persepsi pada Kreativitas Terhadap Kemampuan Pemecahan Masalah Matematis. Jurnal Pendidikan Matematika STKIP Garut; E-Mosharafa.org, 5 (September).

Mandur, Kanisius. Sadra, I Wayan. Suparta, I. N. (2013). Konstribusi Kemampuan Koneksi, Kemampuan Representasi, dan Disposisi Matematis Terhadap Prestasi Belajar Matematika Siswa SMA Swasta di Kabupaten Manggaras. E-Journal Program Pascasarjana Pendidikan Ganesha, 2.

Nasution, E. Y. P. (2016). Analisis Terhadap Disposisi Matematis Siswa SMK pada Pembelajaran Matematika. Logaritma, IV(1), 77-95.

Oktaviani, R. Suyitno, H. M. (2015). Keefektifan Model-Eliciting Activities Berbantuan LKPD Terhadap Kemampuan Komunikasi Matematis dan Disposisi Matematis Peserta Didik Kelas VIII. Unnes Journal of Mathematics Education, 5(3).

Rahmi, S., Nadia, R., Hasibah, B., \& Hidayat, W. (2017). The Relation between Self-Efficacy toward Math with the Math Communication Competence. Infinity Journal, 6(2), 177182.

Sumarmo, U., Hidayat, W., Zukarnaen, R., Hamidah, M., \& Sariningsih, R. (2012). Kemampuan dan Disposisi Berpikir Logis, Kritis, dan Kreatif Matematik (Eksperimen terhadap Siswa SMA Menggunakan Pembelajaran Berbasis Masalah dan Strategi ThinkTalk-Write). Jurnal Pengajaran MIPA, 17(1), 17-33.

Zaini, A. (2014). Perbandingan Keefektifan Pembelajaran Matematika dengan Pendekatan Matematika Realistik dan Konvensional Ditinjau dari Kemampuan Komunikasi Matematik Siswa. JPM IAIN Antasari, 2(1), 1-20.

Zakiah, L., Saomi, A. S. N., Syara, R., Hidayat, W., \& Hendriana, H. (2018). THE EFFICIENCY OF USING EDUCATION VIDEOS ON THE LINEAR PROGRAM MATERIAL AS OBSERVED IN VOCATIONAL HIGH SCHOOL STUDENTS'MATHEMATICAL COMMUNICATION ABILITY. Journal Of Educational Experts (JEE), 1(1), 11-18. 